\title{
Is There Any Mediating Effect of Financial Deepening on the Relationship Between Economic Growth and Poverty Levels in the EAC Countries
}

\author{
James Mageto Nyamweya ${ }^{1,}$, , Duncan Elly Ochieng ${ }^{1}$, Herick Ondigo ${ }^{1}$, Peterson Obara Magutu ${ }^{2}$ \\ ${ }^{1}$ Department of Finance and Accounting, Faculty of Business, University of Nairobi, Nairobi, Kenya \\ ${ }^{2}$ Department Management Science, Faculty of Business, University of Nairobi, Nairobi, Kenya \\ Email address: \\ jamesnyamweya18@gmail.com (J. M. Nyamweya), ellyduncan@gmail.com (D. E. Ochieng), ondigo.erick@gmail.com (H. Ondigo), \\ magutumop@gmail.com (P. O. Magutu) \\ ${ }^{*}$ Corresponding author
}

\section{To cite this article:}

James Mageto Nyamweya, Duncan Elly Ochieng, Herick Ondigo, Peterson Obara Magutu. Is There Any Mediating Effect of Financial Deepening on the Relationship Between Economic Growth and Poverty Levels in the EAC Countries. International Journal of Finance and Banking Research. Vol. 6, No. 4, 2020, pp. 57-64. doi: 10.11648/j.ijfbr.20200604.11

Received: May 27, 2020; Accepted: June 15, 2020; Published: July 23, 2020

\begin{abstract}
The study examined the mediating role of financial deepening on the relationship between economic growth and poverty levels in East African Community countries. The specific objectives included establishing the effect of economic growth on poverty levels in EAC countries and determining the meditating effect of financial deepening on the relationship between economic growth and poverty levels in EAC countries. The positivism philosophy was adopted throughout the study. The study adopted both comparative and descriptive research designs. The study population was the five countries of EAC countries which included Kenya, Rwanda, Uganda, Burundi, and Tanzania. Annual data for 30 years beginning 1989 to 2018 was gathered for the study purpose. Secondary data, which consisted of annual data, was utilized in the study. The study employed normality, heteroscedasticity, multicollinearity, serial correlation and unit root diagnostic tests. The data was analyzed using both descriptive and inferential statistics with the help of excel and STATA version 14. Feasible Generalised Least Squares (FGLS) panel data regression model was adopted to ascertain the causal effect link between various variables relating to economic growth, financial deepening, and poverty levels in EAC member countries. The tests of hypotheses were examined at $95 \%$ confidence level. The study results revealed that economic growth had a significant effect on poverty levels in East African Community countries. The study also revealed that financial deepening has a significant mediating effect on the link between economic growth and poverty levels in East African Community countries.
\end{abstract}

Keywords: Financial Deepening, Economic Growth, Economic Integration and Poverty Levels

\section{Introduction}

Globally, the economic problem of poverty has been an area of concern for decades as world economies pool their resources to fight poverty. Obuya and Olweny (2017) showed that policies have been developed based on theoretical studies on the determinants of poverty [1-2]. One of the policy areas has been the financial development front based on the finance and development nexus. The association between economic growth, financial deepening, income distribution, financial efficiency and poverty levels in national economies has been an area of concern for scholars in both the developed nations and developing counterparts [3]. A financial system tends to increase the breath and access to funds while on the other hand; a financial system that is underdeveloped limits the access to funds by people [4].

Economic growth occurs when productive potential in an economy increases, and that it is best measured by evaluating increase in national real output value over a given period of time [5]. This means increase in the real Gross Domestic Product (meaning that it has been adjusted to take care of inflation). Economic growth is a health indicator of an economy [6]. Additionally, when comparing countries of various population sizes, the per capita figure is usually cited. 
To make up for changes in the value of money, the GDP or GNP is usually stated in real terms that have been adjusted for inflation or deflation [7].

Financial deepening refers to improving access to financial services. Additionally, it may describe a situation of wider option of financial services and improved access to financial services among different socioeconomic groups in an economy [8]. The term is used by economists to depict increase in provision of financial services, particularly in terms of the number of choices and access that people in different socioeconomic groups have in an economy $[9,10]$. Consequently, financial deepening mean that agents and sectors are in a position to utilize money and capital markets for the purpose of investment and savings, including access to capital and money market assets like loans, insurance policies, government bonds and treasury bills [11].

Poverty can also be described as the lack of a given quantity of material possessions such as money. The concept and condition of Poverty is multifaceted including economic, social and political element [12]. The term absolute poverty describes the inadequate access to means of satisfying basic needs, which include shelter, clothing and food [13]. This is uniform worldwide regardless of where one lives geographically or the era one lives in. Poverty is the deprivation of well-being. Other scholars claim that poverty has many dimensions because it includes incapability to get basic goods and services that are necessary for human survival and low income among other things [14-15]. There are a number of proxies that have been adopted in the literature to measure poverty. One of a leading measure of poverty is head count ratio measure. The head count ratio has been defined as the percentage of the total population whose earning is below the poverty line. Given that time series data on poverty is incomplete for most countries, scholars have tended to estimate annual poverty headcount ratio based poverty changes decomposition that is based on the general concept that the leading cause of changes in poverty in the long run is economic growth and income distribution.

This study, attempted to address a number of knowledge gaps. Firstly, most of the studies that examine the effects of economic growth on reducing poverty in the EAC region focus on individual countries. They have limited application in the context of EAC countries as a whole [16-20]. Secondly, the majority of studies have ignored mediating effect of financial deepening on the association between economic growth and poverty which is contrary to the growth-finance-poverty nexus literature [21-23]. In this respect, this study examined the link between economic growth, financial deepening and poverty levels in EAC countries.

\subsection{Research Objective}

1. To determine the mediating effect of financial deepening on the relationship between economic growth and poverty levels in EAC countries.

\subsection{Research Hypothesis}

1. Financial deepening has no significant mediating effect on the relationship between economic growth and poverty levels in EAC countries.

\section{Literature Review}

\subsection{Theoretical Review}

The study was based on two major theories, Liberal Theory and Financial intermediation theory. Liberal theory revolves around the idea that poverty in an economy is caused by both market distortions and underdevelopment in various areas. This theory was formulated by Keynes who believed that market forces were capable of promoting economic growth and in turn was able to eradicate poverty [24]. Based on this belief, Keynes justified government's interventions at macroeconomic level especially in handling involuntary unemployment. From a liberal perspective, poverty is defined as the misfortune of a small group of people who cannot work even if they wished to work. As a consequence, governments should regulate as opposed to impose its rule on poverty reduction [25]. The liberal theory argues that poverty can be used to reflect the extent to which market forces fail to justify redistributive taxation in kind and cash. Even with the contribution of liberal theory to growth, employment and poverty analysis, opponents of the theory argue that it is an inadequate, indeterminate, unrealistic, incomplete and unrealistic theory of interest rate. There are certain inherent defects that are suffered from aggregate demand that make job creation unrealistic [26]. Keynes thereby treated demand as simple and in so doing forgot to acknowledge the fact that relative prices that prevailed in different sectors in a way determined part of the total amounts of outlays. Even with the above criticisms, liberal theory is of great importance as economic growth leads to development that in turn leads to poverty eradication.

The financial intermediation theory postulates that the financial intermediation process includes economic units with surplus funds deposited with financial institutions who in turn lend the same funds to economic units with deficit funds [27]. Generally, financial intermediaries exist in the financial markets because of the very nature of market imperfections concerning surplus units and deficit units. In a 'perfect' financial market condition where there are no information and transaction costs, financial intermediaries would not exist since they would be serving no purpose. In reality, most financial markets are characterized by information asymmetry hence there exist differences in access to market information between buyers and sellers of financial products. Financial markets have pronounced and elevated levels of information asymmetries that make it crucial that intermediaries should exist to bridge the gap in information and make flow of finances within an economic system practicable [28]. Financial intermediation is made possible with financial institutions acting as the intermediary between those who have surplus finances and those with 
deficit financing [1]. The theory underpins the current study by examining the contributions of financial intermediation to financial deepening and efficiency. Financial intermediation ensures that those with excess funds are connected with those who need finances to start business ventures. The purpose of financial intermediation is to reduce the intermediation cost hence efficiency in the financial system.

\subsection{Empirical Review}

Economic growth and poverty level: Research analyzed the causal connection between poverty and economic growth in less developed nations between the period 1970 and 1998 [16]. The investigation applied Granger causality tests and panel data specification. The examination implied that economic development causes unidirectional decrease in poverty level. A Kenyan study evaluated the connection between economic growth, poverty and development of financial sector in Kenya for the period between 1997 and 2012 [17]. The examination utilized OLS technique under the PARCH model. Since the study was carried out in Kenya, it may not be readily applicable to other EAC Countries due to each country's inequalities. In addition, the study has not introduced income inequality as a mediating variable as postulated in growth poverty theory which states that economic growth can impact on poverty directly or indirectly through income distribution.

A study analyzed how connection between poverty and growth can vary depending on income inequality and economic development [18]. Utilizing the possibility of poverty elasticity of income, estimating the degree to which economic development diminishes poverty, the examination offers a few suggestions to exhibit that the underlying dimensions of income inequality and economic growth can affect reduction in poverty. Further, the study exhibits that tradeoff between economic growth and income inequality can be clarified as far as initial states of income inequality and development. The study however, was not based on the East African community countries. In addition, the study utilized income inequality to measure poverty, which may not be a better measure since income is relative and can only measure relative poverty but cannot capture absolute poverty.

An empirical study in selected countries in Africa investigated the link between growth of economy, development of financial sector and poverty reduction in nine African nations using the data from 1970 to 2013. The study adopted the Autoregressive Distributed-lagged model [19]. The study established a strong relationship between GDP and financial deepening with GDP positively affecting poverty decrease in five nations including South Africa, Cote d'Ivoire, Benin, Cameroon and Gabon's GDP also affected decrease in poverty positively affecting growth of economy in three nations including Senegal, Nigeria and Ghana. The examination likewise uncovers two-way causation between poverty reduction and financial development in South Africa, Gabon and Cote d'Ivoire and two-way causality between reduction of poverty and development of financial sector in South Africa, Cameroon and Benin. The findings were mixed concerning direction of causation between financial deepening, economic growth and poverty. The study model ignored the role of income distribution on poverty reduction as stated in economic theory that income inequality moderates the relationship between poverty and income growth.

Economic Growth, Financial deepening and poverty: A research examined the association between economic development and financial deepening in Nigeria for the period between 1986 and 2007. The study adopted two stages least squares regression and established that financial deepening proxies had a statistical association with economic growth [23]. The study was however limited to Nigeria in addition to using financial deepening as an independent variable. A Kenyan study analyzed the link between poverty and financial development in Kenya [29]. The study established that financial development Granger contributed significantly to domestic savings thereby reducing poverty levels within the country. However, the direction of causation between poverty reduction and financial deepening had mixed findings when different proxies of financial deepening are used which may be misleading. The study was limited to Kenya hence findings may not be readily adopted in the five countries of the EAC owing to different economic situations.

Another study examined the causal link between inequality, financial development and poverty in African nations. The study established that income inequality and poverty were affected significantly by financial development in the African Nations studied [30]. The study established insignificant influence of finance on poverty that is conflicting with expectations based on finance- poverty nexus literature. In addition, the study employed income inequality as co-dependent variable with poverty which is conflicting with general theoretical expectation that states that income inequality would mediate the link between poverty and finance. A research in Bangladesh analyzed the association between growth of economy, poverty reduction and development of financial sector in Bangladesh [31]. The study used quarterly data from 1975 to 2011. The study established that economic growth was largely influenced by developments made in the financial sector whereas poverty was influenced by growth. The study was based in Bangladesh with unique economic environment compared to East African Community Countries. The study utilized consumption among private households as poverty proxy, which might be misleading since the measure does not capture correctly absolute nature of poverty. Income inequality was ignored in the analysis model conflicting finance-growth-poverty literature that uses inequality to capture the indirect effects of growth on poverty via inequality.

A study carried out in Egypt analyzed the association between poverty eradication and development of financial sector in Egypt using quarterly data for the period between the first quarter of 1975 and the last quarter of 2011 [32]. The results revealed that poverty rates are reduced by financial development. The study was conducted in Egypt, which has 
different economic situations hence results may not be used in EAC Countries for policy recommendations. In addition, the study focused on the direct effect of financial deepening on poverty only while ignoring the indirect effects otherwise known as trickle-down effect. Finally, causality between finance and poverty is not significant which may be misleading since finance and poverty nexus theories show significant relationships. Another study examined the link between financial development, inequality and poverty [33]. They utilized a sample of 143 countries and focused on the period between 1961 and 2011. They established that the components of financial deepening especially those related to banking sector were able to reduce poverty and income inequality. The study uses poverty gap index to measure poverty that may be misleading, as it does not capture the differences in the severity of poverty amongst the poor. Poverty gap index is also a recent proxy for poverty and is lacking for years before 2000 .

\section{Methodology}

The positivism philosophy was adopted throughout the study. The philosophy was adopted because like natural sciences; the current study intends to test hypotheses on the link between economic growth, financial deepening, income distribution, financial efficiency and poverty levels. The study adopted a descriptive research designs. The design was preferred as the study attempts to investigate the link between economic growth, financial deepening, income distribution financial efficiency and poverty levels in EAC countries.

The study population was five countries in the EAC, which included Kenya, Rwanda, Uganda, Burundi, and Tanzania. South Sudan was omitted because it is not a full member of the EAC. Annual data for 30 years beginning 1989 to 2018 was gathered for the study purpose. Secondary data, which consisted of annual data, was utilized in the study. The data relating to credit to the private sector was obtained from respective websites of central banks of the EAC countries. The real GDP data was gathered from World Bank's website whereas data on cost efficiency of the respective banking sector was gathered from the website of Central Banks of EAC countries and IMF. Data on headcount ratio and Gini coefficient was acquired from the World Bank and African Development Bank websites. The study collected annual data for 30 years from 1989 to 2018 from five EAC countries. Diagnostic tests were carried out to examine the conformity of the empirical model to classical ordinary least squares assumptions. The study employed normality, heteroscedasticity, multicollinearity, serial correlation, unit root diagnostic tests. The process of analyzing the data started start by sorting, classifying, collating and checking for the data completeness. The data were then tabulated in to Microsoft excel and various variables generated. The excel file was then be exported to STATA version 14 for further analysis. The descriptive statistics, which included skewness, minimum and maximum values, standard deviation and mean among others, will be calculated and tabulated. Diagnostic tests were then carried out and finally inferential statistics analysis were performed based on Feasible Generalized Least squares (FGLS) panel data regression models The tests of hypotheses were examined at $95 \%$ confidence level. The regression was based on the models in Table 1.

Table 1. Regression Models.

\begin{tabular}{ll}
\hline Hypotheses & Analysis Models \\
\hline & Hierarchical Regression \\
& $\mathrm{Y}_{\mathrm{jt}}=\beta_{0}+\beta_{1} \mathrm{X}_{\mathrm{jt}-1}+\varepsilon$ \\
& $\mathrm{U}_{\mathrm{jt}}=\beta_{0}+\beta_{1} \mathrm{X}_{\mathrm{jt}-1}+\varepsilon$ \\
& $\mathrm{Y}_{\mathrm{jt}}=\beta_{0}+\beta_{1} \mathrm{X}_{\mathrm{jt}-1}+\beta_{2} \mathrm{U}_{\mathrm{jt}-1}+\varepsilon$ \\
& Where: \\
$\mathrm{H}_{01}$ : Financial Deepening has & $\mathrm{Y}=$ Poverty Level (Dependent Variable) \\
no significant mediating effect & $\mathrm{X}=$ Real GDP (Economic Growth) \\
on the relationship between & $\mathrm{U}=$ Financial Deepening (Mediating \\
Economic growth and poverty & variable) \\
levels in EAC Member & $\beta 1, \beta 2$ and $\beta 3=$ coefficient of Explanatory \\
countries. & variables \\
& $\beta 0=$ Constant \\
& $\mathrm{j}=1,2,3,4,5$ (Country) \\
& $\mathrm{t}=$ Current tie period \\
& $\mathrm{t}-1=$ lagged one period \\
& $\varepsilon=$ error term \\
\hline
\end{tabular}

\section{Results}

\subsection{Descriptive Analysis}

Descriptive statistics for all the variables were conducted to determine the statistical properties of the data before making an estimation. This involved the use of descriptive statistical tools including mean, standard deviation, minimum and maximum. Summary of descriptive statistics is presented in Table 2.

Table 2. Summary of Statistics.

\begin{tabular}{llllll}
\hline Variable & Obs & Mean & Std. Dev. & Min & Max \\
\hline $\mathrm{Y}$ & 150 & 60.005 & 16.433 & 31.108 & 86 \\
$\mathrm{X}$ & 150 & $1.62 \mathrm{e}+10$ & $1.51 \mathrm{e}+10$ & $1.23 \mathrm{e}+09$ & $6.18 \mathrm{e}+10$ \\
$\mathrm{U}$ & 150 & $2.63 \mathrm{e}+09$ & $4.72 \mathrm{e}+09$ & $7.45 \mathrm{e}+07$ & $2.46 \mathrm{e}+10$ \\
\hline
\end{tabular}

Table 2 presented the mean, standard deviation, minimum and maximum point. All the observations (Obs) were 150 with the exception of income distribution. The 150 observations were generated by getting the product of the time period and the number of the countries. Since the time was 30 years, from 1989 to 2018 , and there were five countries, the observations were thus $(30 * 5)=150$.

The mean for poverty measured by head count ratio for all the five countries considered in the study was $60 \%$. The poverty average mean means that on average for the 30 -year period of the study, poverty level has remained high in East African countries with more than $60 \%$ of the population earning less than 2 USD per day. The standard deviation was 16.43 meaning specific country poverty levels deviated away from the mean by about $16.4 \%$. The minimum poverty level was $31.1 \%$ and the maximum 
poverty level was $86 \%$.

The economic growth was measured by real GDP in USD. The average economic growth was USD 162 billion, the standard deviation was USD 151 billion implying the economic growth of the East African Community countries is spread around the mean by USD 151 billion. The highest economic growth was USD 618 billion and the minimum economic growth was USD 12.3 Billion. Financial deepening was measured by credit to the private sector. The mean financial deepening was USD 26.3 Billion while the standard deviation for financial deepening was USD 47.2 billion. Finally, maximum financial deepening was USD 246 and minimum financial deepening was USD 0.745 Billion.

\subsection{Diagnostic Tests}

These tests were carried out to examine the conformity of the empirical model to classical ordinary least squares assumptions. This ensured that the model is fit and robust for the purpose of forecasting. The study tested panel data classical least squares assumptions including normality, heteroscedasticity, multicollinearity, serial correlation, unit root diagnostic tests, cross-sectional correlation.

Shapiro-wilk Test for Normality: All the p-values were less than 0.05 meaning there of a problem of normality hence Least Squares Assumptions of normality of observed variables and residuals is violated hence the study adopted FGLS model for parameter estimation.

Variance Inflection Factor (VIF) test for Mulltocolliniarity: All the explanatory variables had a VIF value less than 10 . The explanatory variables therefore showed a lower VIF value. With no explanatory variables showing signs of multicollinearity, the classical least squares panel data model may be appropriate for the analysis. However, for the study to classical least squares panel data model, there should be no violation of heteroscedasticity, unit roots and autocorrelation assumptions.

Modified Wald Test for Heteroscedasticity: The p-value $(0.0000)$ was less than the significance level $(0.05)$ hence the test concluded that there is no constant variance meaning the error terms are heteroskedastic and the OLS assumptions of homoscedasticity is violated. An attempt to remove heteroscedasticity by getting robust standard errors and did not solve the problem. The study therefore ignored the Ordinary Least Squares panel model regression model and adopted FGLS model.

Wooldridge Test for autocorrelation: The results showed that the p-value (0.0003) was less than the significance level (0.05) hence the test rejects the null hypothesis of no autocorrelation implying that the data has strong serial correlation. In addition utilizing first order difference data transformation of the variables did not eliminate autocorrelation. Hence, the Ordinary least squares (OLS) assumption of no autocorrelation is violated. The study had to make a choice between Panel Correlated Standard errors (PCSE) model and Feasible Generalized Least Squares (FGLS) model. The study settled on FGLS given that it is used when T $>$ n ( $T=30$ years and $n=5$ countries).

Levin-Lin-Chu unit-root test:

Since the P-value for poverty $(0.9385)$ financial deepening (0.7819) and economic growth (0.9171) were all greater than the significance level $(0.05)$, the test fails to reject the null hypothesis that panels contain unit roots hence the variables have unit roots meaning the variable are significantly affected by time and may result in spurious regression. In conclusion, given that all the variables showed presence of unit roots with P-values being greater than 0.05 except financial efficiency. The study therefore concluded that the effect of change in time on parameter estimates is significant. Hence, classical least squares panel model cannot be adopted. The study therefore adopted FGLS model in parameter estimation.

\subsection{Correlation Analysis}

The study adopted correlation analysis to assist explain the association between economic growth, financial deepening, income distribution and financial efficiency and poverty levels among east African community countries. The study also used pairwise Pearson Correlation to establish the relationship as shown in Table 3.

Table 3. Pairwise Correlation Coefficients.

\begin{tabular}{llll}
\hline Variables & (1) $\mathrm{Y}$ & (2) $\mathrm{X}$ & (3) $\mathrm{U}$ \\
\hline (1) $\mathrm{Y}$ & & & \\
(2) $\mathrm{X}$ & $-0.748^{*}$ & 1.000 & \\
& 0.000 & & \\
(3) $\mathrm{U}$ & $-0.824^{*}$ & $0.880^{*}$ & 1.000 \\
& 0.000 & 0.000 & \\
\hline
\end{tabular}

* shows significance at the .05 level.

Table 3, Pairwise Pearson correlation coefficient was generated at 0.05 level of significance. The correlation between financial deepening and poverty level was negative and statistically significant $(\mathrm{r}=-0.824, \mathrm{p}=0.0000<$ $\alpha=0.05$ ). The relationship between economic growth and poverty level was negative and statistically significant $(\mathrm{r}=0.748, \mathrm{p}=.000<\alpha=0.05)$. All the explanatory variables were negatively correlated with poverty levels in east African countries (Kenya, Uganda, Tanzania, Burundi and Rwanda).

\subsection{The Mediating Effect of Financial Deepening on the Relationship between Economic Growth and Poverty Levels}

The study sought to test the null hypothesis $\left(\mathrm{H}_{01}\right)$ that Financial Deepening has no significant mediating effect on the relationship between economic growth and poverty levels in EAC member countries. The hypotheses test was based on $\mathrm{p}$ values of FGLS regression analysis. Null hypothesis 1 would be rejected if three conditions were satisfied. For the first condition, the first step of regression, p-value associated with economic growth should be less than 0.05 level of significance ( $\mathrm{p}$-value $<0.05$ ). The second condition is that the $\mathrm{p}$ value associated with economic growth generated in the second step of regression should be less than 0.05 level of significance $<$ 
0.05 . The third condition is that $\mathrm{p}$-values generated in the third step regression associated with financial deepening should be less than 0.05 level of significance and $\mathrm{p}$ associated with economic growth should be greater than 0.05 for there to be complete mediation if $p$ values for both economic growth and financial deepening are both less than 0.05 then there is partial mediation. The findings are presented in Table 4.

Table 4. Mediating Effect of Financial Deepening on the Relationship between Economic Growth and Poverty Levels.

\begin{tabular}{llll}
\hline & $\mathbf{( 1 )}$ & $\mathbf{( 2 )}$ & $\mathbf{( 3 )}$ \\
\cline { 2 - 4 } & $\mathbf{Y}$ & $\mathbf{U}$ & $\mathbf{Y}$ \\
\hline X_01 & $-0.135^{* * *}$ & $0.952^{* * *}$ & $-0.103 * * *$ \\
U_01 & $(0.019)$ & $(0.100)$ & $(0.021)$ \\
& & & $-0.029 * * *$ \\
cons & & & $(0.011)$ \\
& $7.122 * * *$ & -1.031 & $7.007 * * *$ \\
Obs. & $(0.401)$ & $(2.246)$ & $(0.367)$ \\
Pseudo $\mathrm{R}^{2}$ & 145 & 145 & 145 \\
\hline
\end{tabular}

Standard errors are in parenthesis.

$* * * \mathrm{p}<0.01, * * \mathrm{p}<0.05, * \mathrm{p}<0.1$.

Table 4 showed that p-value (0.000) associated with estimated coefficient of economic growth was less than 0.05 level of significance ( $p$-value $=0.000<\alpha=0.05$ ). Further, the model was estimated as shown in model (1).

$$
\mathrm{Y}_{\mathrm{jt}}=7.122-0.135 \mathrm{X}_{\mathrm{jt}-1}
$$

In the fitted (1), Intercept term $\beta_{0}$ (7.122) gives the level of poverty when the explanatory variables are held constant at zero. The coefficient of economic growth $(\beta 1=-0.135)$ was negative meaning a growing economy is also associated with falling poverty levels as citizen's income improves. The first condition for rejection of the hypothesis one was satisfied given that the $\mathrm{p}$-value associated with economic growth was less than 0.05 level of significance ( $p$-value $<0.05$ ).

In the second step of mediation process for hypothesis 1 test, the $\mathrm{p}$-value (0.000) associated with economic growth on financial deepening generated was less than 0.05 level of significance $(p=0.000<\alpha=0.05)$. The $p$-value being less than the level of significance means that economic growth has a significant effect on financial deepening. The model was thus estimated as shown in (2).

$$
\mathrm{U}_{\mathrm{jt}}=-1.031+0.952 \mathrm{X}_{\mathrm{jt}-1}
$$

In the fitted (2), Intercept term for the model (-1.031) gives the level of financial deepening when economic growth is held constant at zero. The coefficient of economic growth $(\beta 1=0.952)$ was positive meaning a unitary growth in economy in terms of real GDP, ceteris paribus, is associated with rising financial deepening by 0.952 units. Given that the $\mathrm{p}$-value (0.000) associated with economic growth on financial deepening generated in the second step of regression was less than 0.05 level of significance $(p=0.000<\alpha=0.05)$, the second condition for rejection of the null hypothesis 2 was thus satisfied.

In the third step of mediation process for hypothesis 1 test, the p-values for economic growth and financial deepening, ( $p$-value $=0.000$ and $p$-value $=0.006$ ) respectively were less than the level of significance (0.05), implying both variables had a significant effect on poverty levels in EAC countries. The model is thus estimated as shown in (3).

$$
\mathrm{Y}_{\mathrm{jt}}=7.007-0.103 \mathrm{X}_{\mathrm{jt}-1}-0.029 \mathrm{U}_{\mathrm{jt}-1}
$$

In the fitted model, Intercept term for model equation (7.007) gives the level of poverty when economic growth and financial deepening held constant at zero. The coefficient of economic growth $(\beta 1=-0.103)$ was negative meaning a unitary growth in economy in terms of real GDP, ceteris paribus, is associated with falling poverty level by 0.103 units. The coefficient of financial deepening $(\beta 2=-0.029)$ gives the indirect effect of economic growth on poverty through financial deepening and that a unitary increase in financial deepening through credit to the private sector is associated with poverty reduction by 0.029 units, ceteris paribus. Given that the $\mathrm{p}$ values associated with economic growth and financial deepening were all significant at 0.05 level of significance, the third condition for rejection of the null hypothesis was thus satisfied.

The three steps for mediation showed that the three conditions for rejection of the null hypothesis one were all satisfied. The study therefore rejected the null hypothesis that financial deepening has no significant effect on the link between economic growth and poverty levels in East African Community countries. The study therefore concludes that financial deepening has a significant meditation effect on the link between economic growth and poverty levels in East African Community countries. Additionally, the effect was negative meaning increase in financial deepening leads to reduced poverty levels.

\section{Conclusion}

Based on the findings on the relationship between economic growth, financial deepening and poverty levels, the study makes a number of conclusions. First, the study concludes that economic growth has a significant effect on poverty levels in East African Community countries. The coefficient of economic growth was negative meaning a growing economy is also associated with falling poverty level as citizens income improves. The finding implies that improvement of economic growth was crucial in enhancing poverty reduction among countries in east Africa. The findings provide an insight into the significant role that economic growth play in reduction of poverty, especially among EAC member countries.

The study also concluded that financial deepening has a significant effect on the link between economic growth and poverty levels in East African Community countries. The coefficient of financial deepening gives the indirect effect of economic growth on poverty through financial deepening. The negative relationship between financial deepening and poverty shows that increased financial deepening through credit to private sectors is associated with falling poverty 
levels among EAC countries. Further, the study reveals that financial deepening is a mediator in the relationship between economic growth and poverty levels among EAC countries. The relationship between economic growth and poverty levels through financial deepening is the indirect effect of growth on poverty reduction.

The study makes a number of recommendations for policy purposes. Given that economic growth has a significant effect on poverty levels in EAC countries, the finding implies that improvement of economic growth was crucial in enhancing poverty reduction among countries in east Africa. The study therefore recommends that the government in general and ministries of planning and economic affairs of EAC countries should put down concrete plans and concerted actions aimed at improving economic growth rates. Additionally, the EAC countries' central banks and the government ministries of finance and treasury should keep the rate of inflation at one digit level to ensure that economic growth is not eroded by increased general price level in the economy. Increased economic growth means improved income for the general population, especially the poor masses. In addition, given that financial deepening had a significant effect on the link between economic growth and poverty levels in East African Community countries. Moreover, the effect was negative meaning increase in financial deepening leads to reduced poverty levels. The study therefore recommends to government of EAC countries in general and regulatory authorities like Central banks to work towards encourage financial deepening within their respective countries. The countries' regulatory authorities should come with policies that ensure the deepening of the financial sector for instance; interest rate should be regulated to ensure that the interest spread is narrow hence making it cheaper for the general population to have access to financial products, especially credit for business startups.

\section{Acknowledgements}

We would like to recognise valuable contributions from Professor Mirie (PhD), Professor Josephat Lishenga (PhD), Dr. Kennedy Okiro (PhD) and Mr Michael Ochieng Obuya (PhD Student).

\section{References}

[1] Obuya, M. O., \& Olweny, T. (2017). Effect of Bank's Lending Behaviour on Loan Losses of Listed Commercial Banks in Kenya. International Journal of Management and Commerce Innovations, 5 (1), 135-144.

[2] Bitler, M., \& Hoynes, H. (2015). Heterogeneity in the Impact of Economic Cycles and the Great Recession: Effects within and across the Income Distribution. American Economic Review, 105 (5), 154-60.

[3] Sinha, R., Pearson, P., Kadekodi, G., \& Gregory, M. (2017). Income distribution, growth and basic needs in India. Routledge.
[4] Otieno, A. (2013). Financial deepening and profitability of commercial banks in Kenya.(Unpublished PhD Dissertation), Nairobi University, Nairobi, Kenya.

[5] Todaro, M., \& Smith, S. (2015). Economic Development, 12th Edition. Jakarta, Indonesia: Bukupedia.

[6] Imran, K., \& Khalil, S. (2012). Contribution of financial development in poverty reduction through industrial growth. International Journal of Asian Social Science, 2 (5), 567-576.

[7] Ayres, R \& Warr, B. (2010). The Economic Growth Engine: How Energy and Work Drive Material Prosperity. Gloucestershire, England: Edward Elgar Publishing.

[8] Cole, S., Sampson, T., \& Zia, B. (2011). Prices or Knowledge? What Drives Demand for Financial Services in Emerging Markets? The Journal of Finance, 66 (6), 1933-1967.

[9] Shaw, E. (1973). Financial deepening in economic development. Oxford University Press, New York).

[10] Rousseau, P., \& Wachtel, P. (2017). What is happening to the impact of financial deepening on economic growth?. Economic inquiry, 49 (1), 276-288.

[11] Ho, S., \& Odhiambo, M. (2011). Finance and poverty reduction in China: an empirical investigation. International Business \& Economics Research Journal, 10 (8), 103114.

[12] Fosu, A. (2017). Growth, inequality, and poverty reduction in developing countries: recent global evidence. Research in Economics, 71 (2), 306-336.

[13] Baulch, B. (2011). Why Poverty Persists: Poverty Dynamics in Asia and Africa. Gloucestershire, England: Edward Elgar Publishing.

[14] Atkinson, A. B. (2019). Measuring Poverty around the World. Princeton, NJ: Princeton University Press.

[15] Chetty, R., Grusky, D., Hell, M., Hendren, N., Manduca, R., \& Narang, J. (2017). The fading American dream: Trends in absolute income mobility since 1940. Science, 356 (6336), 398-406.

[16] Perez-Moreno, S. and Weinhold, D. 2012. Dynamic medium term granger causality between growth and poverty (Unpublished PhD Dissertation), Universidad de Málaga, Spain.

[17] Waiyaki, N. (2013). Financial development, economic growth and poverty in Kenya. University of Nairobi, Unpublished $\mathrm{PhD}$ Dissertation.

[18] Kakwani, N., \& Son, H.(2016). Global poverty estimates based on 2011 purchasing power parity: where should the new poverty line be drawn?. The Journal of Economic Inequality, 14 (2), 173-184.

[19] Keho, Y. (2017). The impact of trade openness on economic growth: The case of Cote d'Ivoire. Cogent Economics \& Finance, 5 (1), 1-14.

[20] Williams, H., Adegoke, A., \& Dare, A. (2017). Role of financial inclusion in economic growth and poverty reduction in a developing economy. Internal Journal of Research in Economics and Social Sciences, 7 (5), 265-271.

[21] Singh, R., \& Huang, Y. (2015). Financial deepening, property rights, and poverty: Evidence from Sub-Saharan Africa. Journal of Banking and Financial Economics, 1 (3), 130-151. 
[22] Gries, T., Kraft, M., \& Meierrieks, D. (2009). Linkages between financial deepening, trade openness, and economic development: causality evidence from Sub-Saharan Africa. World Development, 37 (12), 1849-1860.

[23] Nzotta, S., \& Okereke, E. (2009). Financial deepening and economic development of Nigeria: An Empirical Investigation.

[24] Keynes, J. (1936). The General Theory of Employment, Interest and Money. London: MacMillan.

[25] Bradshaw, J., Williams, J., Levitas, R., Pantazis, C., Patsios, D., Townsend, P.,... \& Middleton, S. (2000, August). The relationship between poverty and social exclusion in Britain. In 26thPaper prepared for the 26th General Conference of The International Association for Research in Income and Wealth Cracow, Poland, 27 August to 2 September 2000.

[26] Schlesinger, A. (1959). The Age of Roosevelt: The Coming of the New Deal. Cambridge: The Riverside Press.

[27] Akerlof, G., (1970). The market for 'Lemons': Quality uncertainty and the market mechanism. Quarterly Journal of Economics, 84 (3), 488-500.
[28] Leland, H., \& Pyle, D. (1977). Informational asymmetries, financial structure, and financial intermediation. The Journal of Finance, 32 (2), 371-387.

[29] Odhiambo, N. M. (2010). Financial deepening and poverty reduction in Zambia: an empirical investigation. International Journal of Social Economics. 43 (3), 205-219.

[30] Fowowe, B., \& Abidoye, B. (2013). The effect of financial development on poverty and inequality in African countries. The Manchester School, 81 (4), 562-585.

[31] Uddin, G. S., Shahbaz, M., Arouri, M., \& Teulon, F. (2014). Financial development and poverty reduction nexus: cointegration and causality analysis in Bangladesh. Economic Modelling, 36, 405-412.

[32] Abosedra, S., Shahbaz, M., \& Nawaz, K. (2016). Modeling causality between financial deepening and poverty reduction in Egypt. Social Indicators Research, 126 (3), 955-969.

[33] Naceur, S., \& Zhang, R. (2016). Financial development, inequality and poverty: some international evidence. International Review of Economics \& Finance, 61 (5), 1-16. 